\title{
Mucus trap in coral reefs: formation and temporal evolution of particle aggregates caused by coral mucus
}

\author{
Markus Huettel ${ }^{1,3, *}$, Christian Wild ${ }^{1,4}{ }^{\text {, Sabine Gonelli }}{ }^{2}$ \\ ${ }^{1}$ Max Planck Institute for Marine Microbiology, Celsiusstrasse 1, 28359 Bremen, Germany \\ ${ }^{2}$ Davao del Norte State College, New Visayas, Panabo City, Davao del Norte, Philippines \\ ${ }^{3}$ Present address: Florida State University, Department of Oceanography, West Call Street, OSB517, Tallahassee, \\ Florida 32306-4320, USA \\ ${ }^{4}$ Present address: UNESCO, Intergovernmental Oceanographic Commission, 1 rue Miollis, 75015 Paris, France
}

\begin{abstract}
Corals exude large volumes of nutrient-containing mucus when exposed to air during low spring tides, as a protective mechanism against desiccation and UV radiation. Currents and waves of the incoming flood detach the mucus from the corals, thereby increasing organic carbon and nutrient concentrations in the reef water. During transport into the reef lagoon, a large fraction of the mucus dissolves. Roller-table experiments demonstrated that this dissolved mucus leads to the formation of marine snow. The non-dissolving gel-like fraction of the mucus rapidly accumulates suspended particles from the flood water and forms in temporal sequence mucus strings, flocs, surface films, surface layers and thick mucus floats. In a platform reef in the Great Barrier Reef, Australia, we characterized each of these mucus phases and observed the exponential increase of algal and bacterial cells in the ageing mucus aggregates. Within 3 hours, the dry weight of the aggregates increased 35 -fold, chlorophyll a 192-fold, bacteria cell density 546-fold, C 26-fold, and N 79-fold. After waves destroy the buoyant mucus floats, the mucus aggregates release enclosed gas bubbles and quickly sink to the lagoon sediments, where they are consumed by the benthic community. This releases aggregate-bound nutrients, which fuel benthic and planktonic production in the lagoon. During ebb tide, corals filter the lagoon water and close the recycling loop. We conclude that coral mucus enhances the filtration capacity of coral reefs and fuels reef benthos, thereby increasing the import of oceanic particles and enhancing recycling in the reef ecosystem.
\end{abstract}

KEY WORDS: Mucus $\cdot$ Coral reefs $\cdot$ Nutrient recycling $\cdot$ Permeable sediment $\cdot$ Marine snow $\cdot$ TEP

\section{INTRODUCTION}

Coral reefs typically grow in oligotrophic waters, and the high gross productivity of these ecosystems (Lewis 1977) is explained by the combination of efficient light capture mechanisms and nutrient recycling, as well as hydrodynamic processes (Hatcher 1990, 1997, Muscatine \& D'Elia 1978, Sorokin 1991, Thomas \& Atkinson 1997). The proportion of energy ultimately derived from symbiotic zooxanthellae photosynthesis ranges from over $95 \%$ in mainly autotrophic corals to about
$50 \%$ in the more heterotrophic species (Barnes \& Hughes 1999). However, up to $50 \%$ of carbon fixation is released by hard and soft corals as mucus that is transported over the surface of the colony (Crossland et al. 1980, Davies 1984). The various functions of this mucus were recently reviewed by Brown \& Bythell (2005). Many corals feed on fine particles in the mucus film or strands, which are drawn by cilia into the polyp's mouth (Lewis \& Pice 1976, Lewis 1978). Suspended particles that come into contact with the coral surface stick to the mucus, which is designed to trap 
particulate matter from the passing water. Coral mucus also functions as a protective mechanism against sedimentation, biofouling, desiccation, and ultraviolet radiation (Hubbard \& Pocock 1972, Schuhmacher 1977, Ducklow \& Mitchell 1979a, Rublee et al. 1980, Hayes \& Goreau 1998, Teai et al. 1998).

Desiccation and ultraviolet radiation are threats when corals become exposed to air at low tide. At Heron Island (our study area in the Australian Great Barrier reef), exposure of corals to air at low tide is a common phenomenon, as is also observed at other reef environments in Australia, New Caledonia, Madagascar, the Red Sea and Hawaii (Daumas et al. 1982, Krupp 1984, Romaine et al. 1997). When exposed to air, as well as under other stress conditions (e.g. polluted waters, increased temperature or turbidity), corals respond with elevated production of mucus (Loya \& Rinkevich 1980, Rublee et al. 1980, Kato 1987, Telesnicki \& Goldberg 1995). Wild et al. (2005) found 13-fold increases from 0.3 to 3.81 mucus $\mathrm{m}^{-2}$ Acropora millepora surface $\mathrm{h}^{-1}$ after exposure at low tide; 56 to $80 \%$ of the released mucus dissolves in the seawater (Wild et al. 2004a) and the rest forms transparent but visible strings, flocs and sheaths.

The mucus is a carbohydrate complex (Coffroth 1990), containing also lipids (Benson \& Muscatin 1974, Crossland et al. 1980) and proteins (Krupp 1985, Vacelet \& Thomassin 1991). Wild et al. (2005) reported that the $\mathrm{C} / \mathrm{N}$ ratios of freshly released mucus from Acropora spp. ranged from 8 to 14, suggesting that the mucus may be a potential food source. The question of whether mucus is a valuable food source arises because water currents and waves remove mucus from the coral, and enhanced mucus production under stress also results in a partial release of mucus to the ambient water (Coles \& Strathma 1973, Coffroth 1983, Crossland 1987), such that suspended particulate matter in coral reefs is often dominated by mucus strings, flocs and sheaths (Johannes 1967, Marshall 1968). Coral mucus efficiently adsorbs particles; thus, mucus strings or sheaths floating in the water column may act as traps for suspended particulate matter. Likewise, bacteria may attach to and colonize the mucus. Hoppe et al. (1988) suggested that relatively high protein content could make coral mucus a major source of nutrients for bacteria, and Sorokin (1991) showed that bacteria grow on mucus. Particle trapping and bacterial colonization may further enhance the value of mucus aggregates as a food source for other reef organisms.

Despite the high abundance of mucus and mucus aggregates in coral reefs, their development over time in the reef water has not been investigated. An understanding of temporal changes in mucus aggregate composition is critical, because these aggregates potentially have an important function in the transfer of energy from the corals to other reef organisms, and in the trapping of organic matter and nutrients from water over passing the reef. The objectives of this study were (1) to assess whether dissolved mucus can cause mucus-particle aggregates, and (2) to assess the changes in particulate coral mucus released to the water over time in order to evaluate whether these aggregates are a potential food source for reef animals.

\section{MATERIALS AND METHODS}

Study site. The field work for this study was conducted in 2001 and 2002 at Heron Island, a small platform reef (11 km long and $5 \mathrm{~km}$ wide) located at the southern end of the Great Barrier Reef, approximately $70 \mathrm{~km}$ off the eastern coast of Australian $\left(23^{\circ} 27^{\prime} \mathrm{S}\right.$, $151^{\circ} 55^{\prime}$ E, Fig. 1). The circular reef rim supports a coral community dominated by Acropora spp., is 20 to $600 \mathrm{~m}$ wide, and encloses a shallow sand-covered lagoon (average depth $1.7 \mathrm{~m}, 19.5 \mathrm{~km}^{2}$ area). During low spring tides, the corals of the reef rim become exposed to air; at Heron Island this can be observed $\sim 6 \mathrm{~d}$ every month (Fig. 2).

Water sampling procedures. On January 13 and 27 , 2002 , time series of water samples were collected over the reef rim and from the adjacent reef channel (i.e. lagoon-ward and sea-ward of the reef crest, Fig. 1) during end of ebb tide, slack tide, and beginning flood tide for assessment of suspended particulate organic carbon, dissolved phosphate and nitrate concentration changes. On both days, corals on the crest of the reef rim were partially exposed to air. At each site, 7 water samples were taken in 30 to $40 \mathrm{~min}$ time intervals

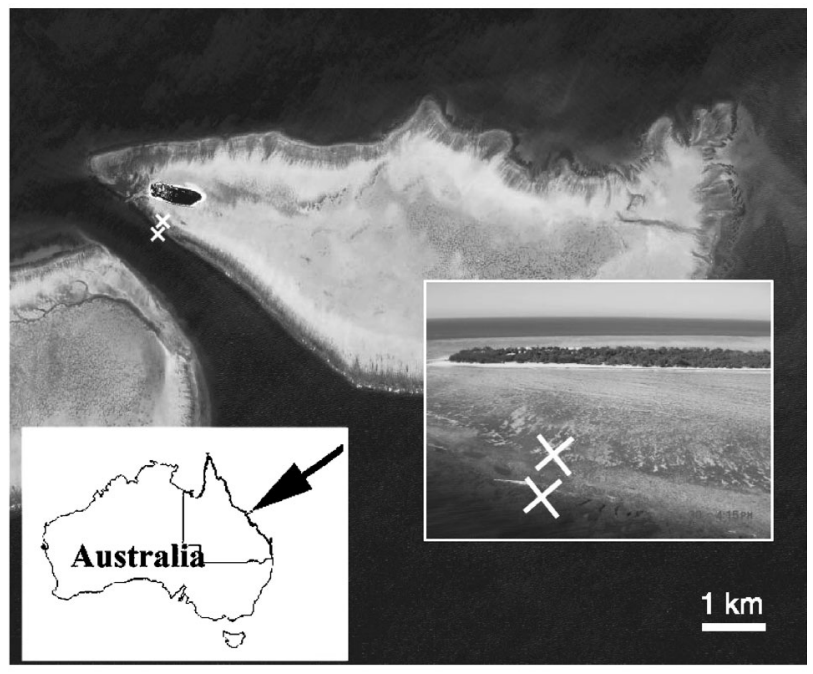

Fig. 1. Location of Heron Island and sampling sites (white crosses) lagoon-ward and sea-ward of the reef rim. (Satellite picture reproduced with permission from Space Imaging) 


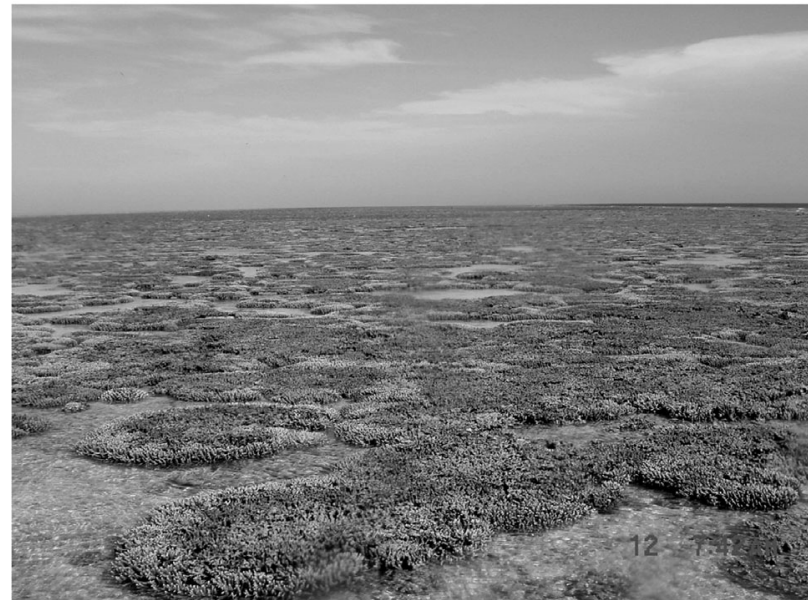

Fig. 2. Partially exposed corals of the Heron Island reef rim during a spring tide

using acid-rinsed 11 PP bottles. Immediately after sampling, exactly 21 of the sampled water was filtered through precombusted GF/F filters and $10 \mathrm{ml}$ of the filtrate was fixed with $0.1 \mathrm{ml}$ saturated $\mathrm{HgCl}_{2}$ for subsequent phosphate and nitrate analyses according to Grasshoff et al. (1999). The dried filters were exposed for $12 \mathrm{~h}$ to fuming $\mathrm{HCl}$ in order to remove calcium carbonate particles, then carbon concentrations on these filters were measured using an elemental analyser (Fisons AT1500) with sulphanilamide (HEKAtech) as the standard.

Sampling of mucus. Temporal change of mucus after its release from corals was investigated during low tides that exposed the reef rim to air. Because exposure initiated a simultaneous release of mucus from many reef rim corals, these exposures set starting points that permitted observation of the transformation of mucus over time. Sampling started at the onset of coral exposure to air and continued past re-immersion of the corals by the incoming flood. Coral mucus strings attached to Acropora spp. corals, and mucus aggregates that have been released from the corals, were collected at the station on the reef rim and pipetted into $3 \mathrm{ml}$ Eppendorf vials using disposable pipettes. Aliquots of each sample were preserved on site with formalin ( $4 \%$ final concentration) for later bacteria cell counts or glutaraldehyde (2.5\% final concentration) for micro algae cell counts. Mucus that covered the corals as a thin liquid film was collected by exposing small singular colonies of Acropora spp. (anchored with their lower dead branches in the reef sediment) to air for $1 \mathrm{~min}$; this resulted in enhanced mucus production by the coral, and mucus drops forming at the tips of coral branches were carefully removed with disposable pipettes. After sampling, the coral colonies were reanchored in the sediment at the original site; thus, no corals were harmed or broken. Water associated with sampled mucus was separated from the mucus prior to analysis; however, some dilution of the mucus by seawater could not be avoided.

Roller-table experiment. In a set of 3 experiments, it was tested whether dissolved mucus with addition of bacteria (Expt 1), planktonic algae (Expt 2), and carbonate particles (Expt 3) leads to the formation of aggregates (Table 1). The experiments were con-

Table 1. Settings for roller-table experiments. T: temperature; S: salinity. Concentrations are means \pm SD

\begin{tabular}{|c|c|c|c|}
\hline Addition/setting & Cylinder 1 & Cylinder 2 & Cylinder 3 \\
\hline \multicolumn{4}{|l|}{ Expt 1} \\
\hline $\mathrm{T}\left({ }^{\circ} \mathrm{C}\right)$ & 26 & 26 & \\
\hline $\mathrm{S}$ & 36 & 36 & \\
\hline Duration (h:min) & $10: 15$ & $10: 15$ & \\
\hline Water (ml) & 150 & 150 & 250 \\
\hline Mucus (ml) & 100 & 100 & \\
\hline Initial bacterial concentration (cells ml ${ }^{-1}$ ) & $2.78 \times 10^{6} \pm 2.57 \times 10^{5}$ & $2.34 \times 10^{6} \pm 5.84 \times 10^{5}$ & $2.22 \times 10^{6} \pm 2.69 \times 10^{5}$ \\
\hline \multicolumn{4}{|l|}{ Expt 2} \\
\hline $\mathrm{T}\left({ }^{\circ} \mathrm{C}\right)$ & 26 & 26 & 26 \\
\hline $\mathrm{S}$ & 36 & 36 & 36 \\
\hline Duration (h:min) & 07:00 & 07:00 & 07:00 \\
\hline Water (ml) & 150 & 250 & \\
\hline Mucus (ml) & 100 & & \\
\hline Initial algal concentration (cells ml ${ }^{-1}$ ) & $8.27 \times 10^{5} \pm 9.94 \times 10^{4}$ & $8.94 \times 10^{4} \pm 4.34 \times 10^{4}$ & \\
\hline \multicolumn{4}{|l|}{ Expt 3} \\
\hline $\mathrm{T}\left({ }^{\circ} \mathrm{C}\right)$ & 27 & 27 & \\
\hline $\mathrm{S}$ & 36 & 36 & \\
\hline Duration (h:min) & $12: 45$ & $12: 45$ & \\
\hline Water (ml) & 150 & 250 & \\
\hline Mucus (ml) & 100 & & \\
\hline Initial particle concentration (particles $\mathrm{ml}^{-1}$ ) & $3.01 \times 10^{4} \pm 1.71 \times 10^{4}$ & $2.04 \times 10^{4} \pm 8.15 \times 10^{3}$ & \\
\hline
\end{tabular}


ducted in a laboratory roller-table set-up as is commonly used for the generation of marine snow (Shanks \& Edmondson 1989). Three (Expt 1) or 2 (Expts 2 and 3) cylindrical containers (inner diameter: $10.9 \mathrm{~cm}$, inner height: $6.0 \mathrm{~cm}$ ) made of transparent acrylic were placed on a roller-table consisting of 2 parallel horizontal revolving bars, which rotated the containers 6 times $\mathrm{min}^{-1}$. Filtered seawater (0.2 $\mu \mathrm{m}$ Millipore) was added to the cylinders, then liquid homogenized coral mucus and a cell or particle suspension was added to the experimental cylinders. The mucus fully dissolved in the water in the cylinders with no visible formation of mucus strings or sheaths. The control cylinder contained only filtered seawater and the different particles, but no mucus.

Coral mucus for these experiments was harvested from Acropora spp. colonies as described above in 'sampling of mucus'. The roller table experiments were started within $6 \mathrm{~h}$ of mucus collection. Bacteria were extracted from $5 \mathrm{l}$ of local seawater by double filtration. Zooxanthellae represented planktonic algal cells and were concentrated by filtration of water from an aquarium containing an Acropora sp. colony, which was in the process of expelling zooxanthellae. Carbonate particles were produced by grinding carbonate sand to an average grain size of $10 \pm 8 \mu \mathrm{m}$ (assessed by a CIS laserdiffraction particle analyzer, GALAI Production), in order to achieve the size fraction $(<20 \mu \mathrm{m})$ commonly observed in natural coral mucus aggregates. Water samples were taken in triplicate aliquots $(1 \mathrm{ml})$ from each container at the start and end of each experiment. Additionally, mucus-particle aggregates were sampled at the end of the experiments. Bacterial and algal samples were preserved with formalin (4\% final concentration) and glutaraldehyde (2.5\% final concentration), respectively. For particle counts, water samples were diluted in $10 \mathrm{ml}$ distilled water and immediately filtered onto $0.2 \mu \mathrm{m}$ carbonate (Millipore) filters. Filters were stained (bacteria) and counted according to procedures explained below for microscopic mucus analysis. For pellet analyses, 3 sub-samples of pellets measuring 10 $\mu \mathrm{l}$ (mucus-bacteria pellet), $20 \mu \mathrm{l}$ (mucus-algae pellet), and $500 \mathrm{\mu l}$ (mucus-carbonate pellet) were gently homogenized in $1 \mathrm{ml}$ of distilled water and then processed as described for water samples.

Mucus analyses. Sub-samples of the mucus samples were prepared on microscope slides and photographed at 10 to $1300 \times$ magnifications. For each mucus phase, 5 to 10 samples were inspected for attached particles, algae and heterotrophic organisms. Algae cell counts were performed using a Zeiss Axiophot epifluorescence microscope. Samples for chlorophyll a (chl a) analysis were prepared by filtering $5 \mathrm{ml}$ of mucus aggregates onto GF/F filters (Whatman). Chl $a$ and phaeophytin concentrations then were determined fluorometrically using standard procedures described in Strickland \& Parsons (1972). Bacteria were counted in sub-samples of the mucus aggregates using the standard Acridine Orange Direct Count method (Hobbie et al. 1977). Samples for carbon and nitrogen content of mucus aggregates were prepared by filtering 5 to $10 \mathrm{ml}$ aggregate (in triplicate aliquots) onto pre-combusted GF/F filters (Whatman). Carbonate particles on the filters were removed by exposure to fuming $\mathrm{HCl}$ for $12 \mathrm{~h}$, and then carbon and nitrogen concentrations on the filters were measured using a Fisons AT 1500 Elemental Analyzer with sulfanilamide (HEKAtech) as the standard. For the sedimentation rate measurements, a 21 measuring cylinder filled with seawater of the same salinity and temperature as recorded in the field was used as a sedimentation column (height: $38.34 \mathrm{~cm}$, diameter: 8.15 $\mathrm{cm})$. Similar quantities $(1 \pm 0.2 \mathrm{ml})$ of freshly collected mucus aggregates of different phases were placed with a pipette just below the water surface, and sedimentation to the bottom of the cylinder was timed. Only mucus aggregates without visible gas inclusions were used. Filter weight was subtracted from the weight of filters with dried mucus to obtain dry mass.

\section{RESULTS}

\section{Suspended particulate organic matter, phosphate and nitrate}

Low water levels during the weeks with spring tide caused the reef rim corals to be exposed to air for a period of up to 3 to $4 \mathrm{~h}$ on 3 to 4 consecutive days. This exposure to air combined with heating and UV stress caused by sunlight triggered intensive mucus production, visible as mucus drops, strings and sheets forming on the corals. Tidal currents and waves detached the mucus from corals and thereby increased suspended particulate organic carbon (POC) concentrations in the water above the reef rim. This POC increase continued throughout low tide and subsequent flooding until flood currents had removed all excess mucus from the coral and flushed these particles into the reef lagoon (Fig. 3). Fresh mucus that was released from Acropora spp. corals was characterised by phosphate (19 to $22 \mu \mathrm{M})$, ammonium (20 to $50 \mu \mathrm{M})$, and $\mathrm{NO}_{\mathrm{x}}(0.6$ to $1.5 \mu \mathrm{M})$ concentrations that far exceeded those of water surrounding the reef $\left(\mathrm{PO}_{4}: 0.05\right.$ to $0.23 \mu \mathrm{M}$, $\mathrm{NH}_{4}{ }^{+}$: not detectable, $\mathrm{NO}_{\mathrm{x}}$ : 0.2 to $1.2 \mu \mathrm{M}$ ) (Wild et al. 2005). The release of mucus from coral during low tide was reflected by phosphate and nitrate concentrations in the reef water: these increased during low and upcoming flood tides beyond the concentrations recorded in ocean water adjacent to the reef (Fig. 4). 

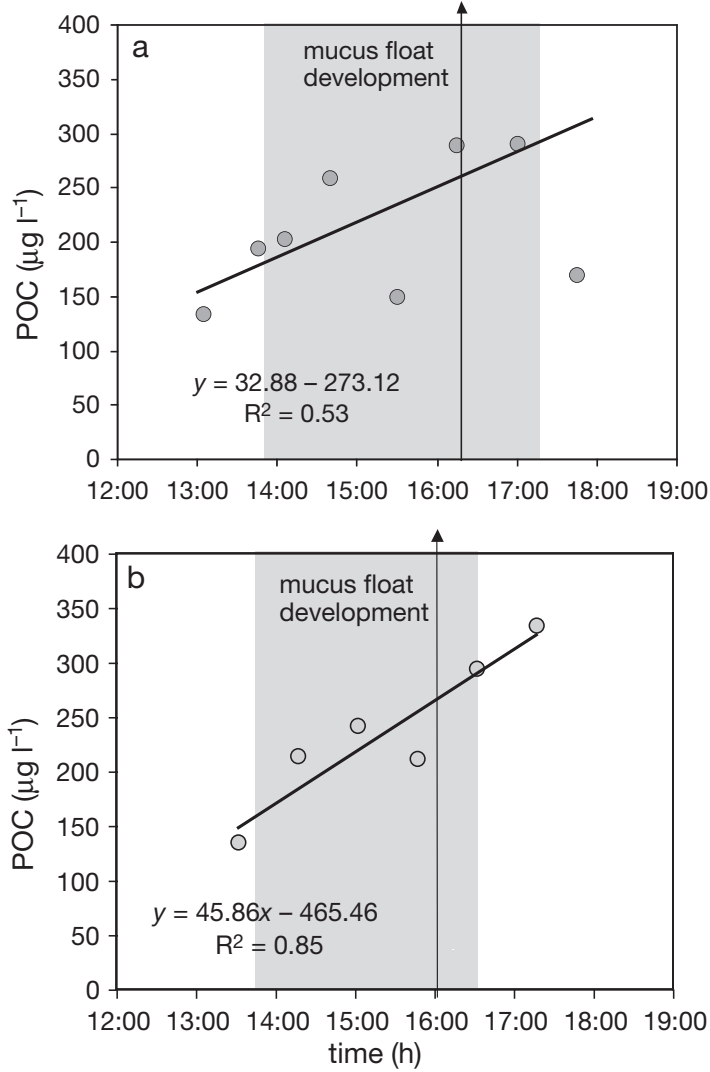

Fig. 3. Suspended POC concentrations in the water over the reef rim, measured on (a) January 13, and (b) January 27 , 2002. Vertical arrows indicate when corals were covered by water

\section{Roller-table experiment}

The roller-table experiment demonstrated that addition of dissolved mucus to water with suspended particles (i.e. bacteria, zooxanthellae, carbonate particles) results in the formation of mucus-particle aggregates (Fig. 5). Within $1 \mathrm{~h}$ after initiation of experiments, small mucus-particle flocs of approximately $1 \mathrm{~mm}$ diameter formed in the cylinders with mucus, reaching concentrations of 0.5 to 1 aggregate $\mathrm{ml}^{-1}$. These flocs, very similar to marine snow (Alldredge \& Silver 1988), persisted throughout the experiments and also formed larger pellets of $\sim 1 \mathrm{~cm}$ length and $\sim 5 \mathrm{~mm}$ diameter during the experimental run. At the end of the incubation, particle concentrations in these pellets exceeded those of the control particle suspensions without mucus by 2 (carbonate particles) and 5 (zooxanthellae, bacteria) orders of magnitude. In contrast, no aggregates were generated in experiments with the same addition of bacteria or carbonate particles, but no addition of mucus. An exception was the control run that contained seawater and zooxanthellae; here, small flocs and a pellet formed, even though no mucus was added.
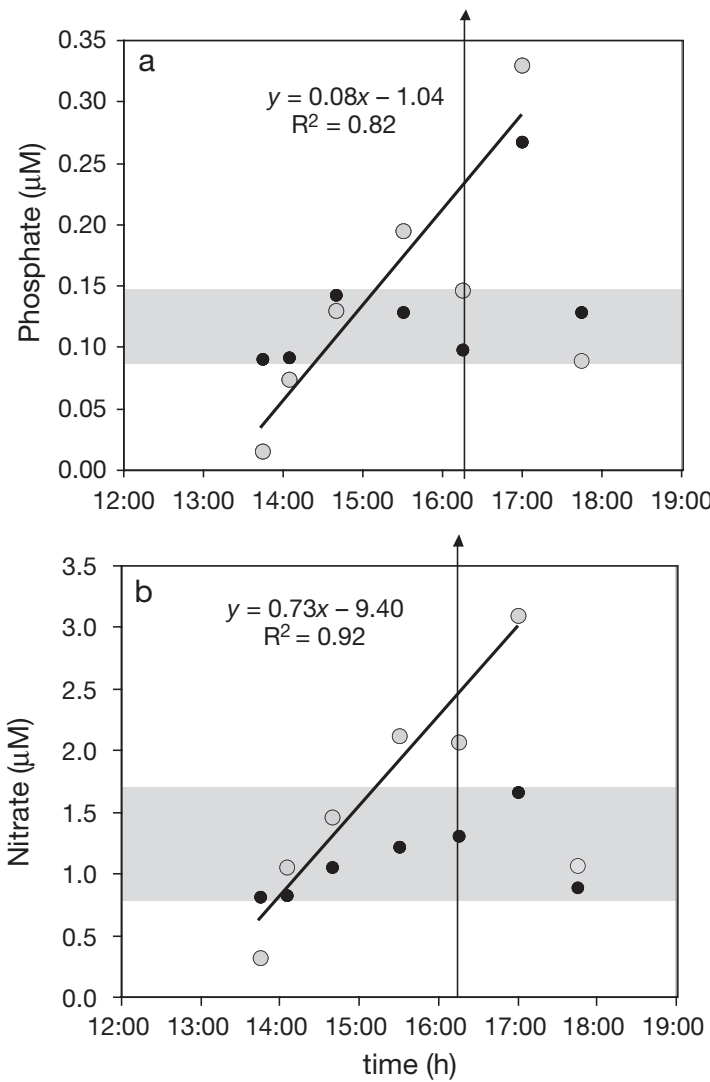

Fig. 4. (a) Phosphate and (b) nitrate concentrations in the water over the reef rim during low and upcoming flood tide on January 13, $2002(\bigcirc)$. Shaded area and $\bullet$ depict the concentration range of the respective nutrient in the adjacent ocean water. High phosphate and nitrate values at 17:00 h may have been caused by a plume of reef water crossing the ocean water sampling site. Vertical arrows indicate when corals were covered by water

\section{Change of mucus aggregates over time}

From the time point of the onset of coral exposure to re-inundation, the released mucus exhibited changes in appearance that we categorized into 6 different phases: 'Phase 1' mucus was defined as the clear, transparent mucus that coats corals at all times (Fig. 6a). Under calm conditions, Phase 1 mucus contained few particles exceeding bacterial size; however, bacterial numbers during our investigation ranged from $9.9 \times 10^{7}$ to $1.2 \times 10^{8}$ bacteria per ml mucus. In 3 of the 6 Phase 1 samples we analyzed, we found zooxanthellae (Fig. 6b) and occasionally also nematocysts. We attributed this finding to stress involved in the harvesting procedure used to remove mucus from the corals. After partial exposure to air during low tide, thin coral mucus cover initially became thicker due to enhanced production, until mucus started to separate from the coral branches. Strings that formed during this process were termed 'Phase 2' mucus (Fig. 6b). These strings 

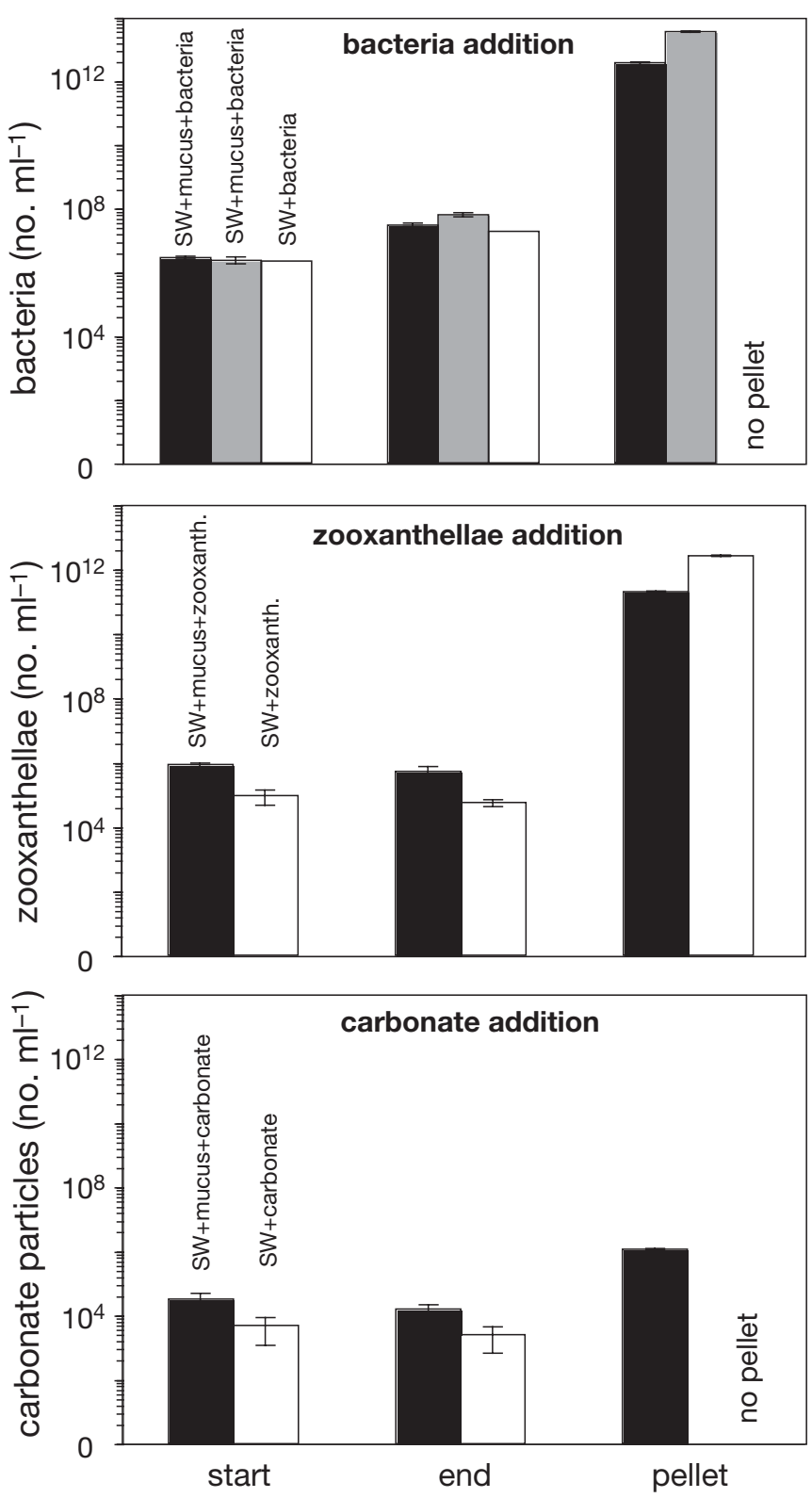

Fig. 5. Results of the roller table experiment with mucus after addition of bacteria, algal cells, or carbonate particles $(10 \mu \mathrm{m})$. $\mathrm{SW}=$ seawater. Error bars $=\mathrm{SD}, \mathrm{n}=3$

were still attached to the coral branches and accumulated particles from the recessing water and, thus, may have contained a higher concentration of particles compared to Phase 1 mucus. Production of strings was not restricted to corals exposed to air, but could also be frequently observed on corals at depths of several metres. Due to viscous forces, water currents and waves pulled mucus and mucus strings from the coral branches resulting in 'Phase 3' mucus-detached ascending mucus aggregates (Fig. 6c). These aggregates were positively buoyant due to small trapped air bubbles (<1 mm diameter) and lipid content and ascended to the surface, accumulating small particles from the water column on the way.

At the surface, mucus aggregates accumulated to form a transparent, slightly milky surface film termed 'Phase 4' mucus (Fig. 6d). Trapped bubbles and particles, in particular minute carbonate grains, were responsible for the milky appearance. Wind and waves folded and compressed the surface film into a surface layer several mm thick that was yellow/green in color; this was defined as 'Phase 5' mucus (Fig. 6e). The color change was caused by increased concentrations of trapped algae, detritus particles and carbonate grains. The final 'Phase 6' mucus floats (Fig. 6f) were formed when wind, waves and currents compacted the surface layer, at the same time enclosing larger air bubbles (<10 mm diameter) and larger particles. Due to the relatively high viscosity of mucus/particle aggregates at this stage, Phase 6 mucus could trap centimeter-long algal strings, foraminifera, small crustaceans, fish larvae, sand grains, detrital material, and mollusk shells.

The development from Phase 1 mucus (clear coral coating) to Phase 6 mucus (foaming surface floats) took approximately $2.5 \mathrm{~h}$. The change from one mucus phase to the next depended on numerous factors (e.g. wind, air, water temperature, local currents, wave action, particle concentration in the water); thus, the 'life time' of the 6 mucus phases was variable and lasted between 15 and 45 min each. In subsequent figures, we used an average phase duration of 30 min on time axes that illustrate changing characteristics of coral mucus during low tides. Because mucus was released continuously, all mucus phases up to and including the 'oldest' phase for the respective time point were always present during the low tide period. Therefore, subsequent figures address the characteristics of the 'oldest' phase present at each time point plotted.

\section{Composition of the different mucus phases}

Mucus harvested from Acropora millepora had a dry mass of $1.68 \pm 2.17 \mathrm{~g} \mathrm{l}^{-1}$ and according to the composition analyses of Meikle et al. (1988) contained 23 to $47 \mathrm{mg} \mathrm{l}^{-1}$ carbohydrates, and 3 to $5 \mathrm{mg} \mathrm{l}^{-1}$ lipids. A protein content of 13 to $26 \mathrm{mg} \mathrm{l}^{-1}$ resulted in a $\mathrm{C} / \mathrm{N}$ ratio of 8 to 14. Details of the harvested mucus composition are given in Wild et al. (2005). This harvested mucus was obtained without contact to seawater and was thus not diluted and, furthermore, may have been affected in its composition by the harvesting procedure. We did not include data obtained from harvested mucus in the trend calculations reported below; however, the respective data points have been depicted to allow comparison. 

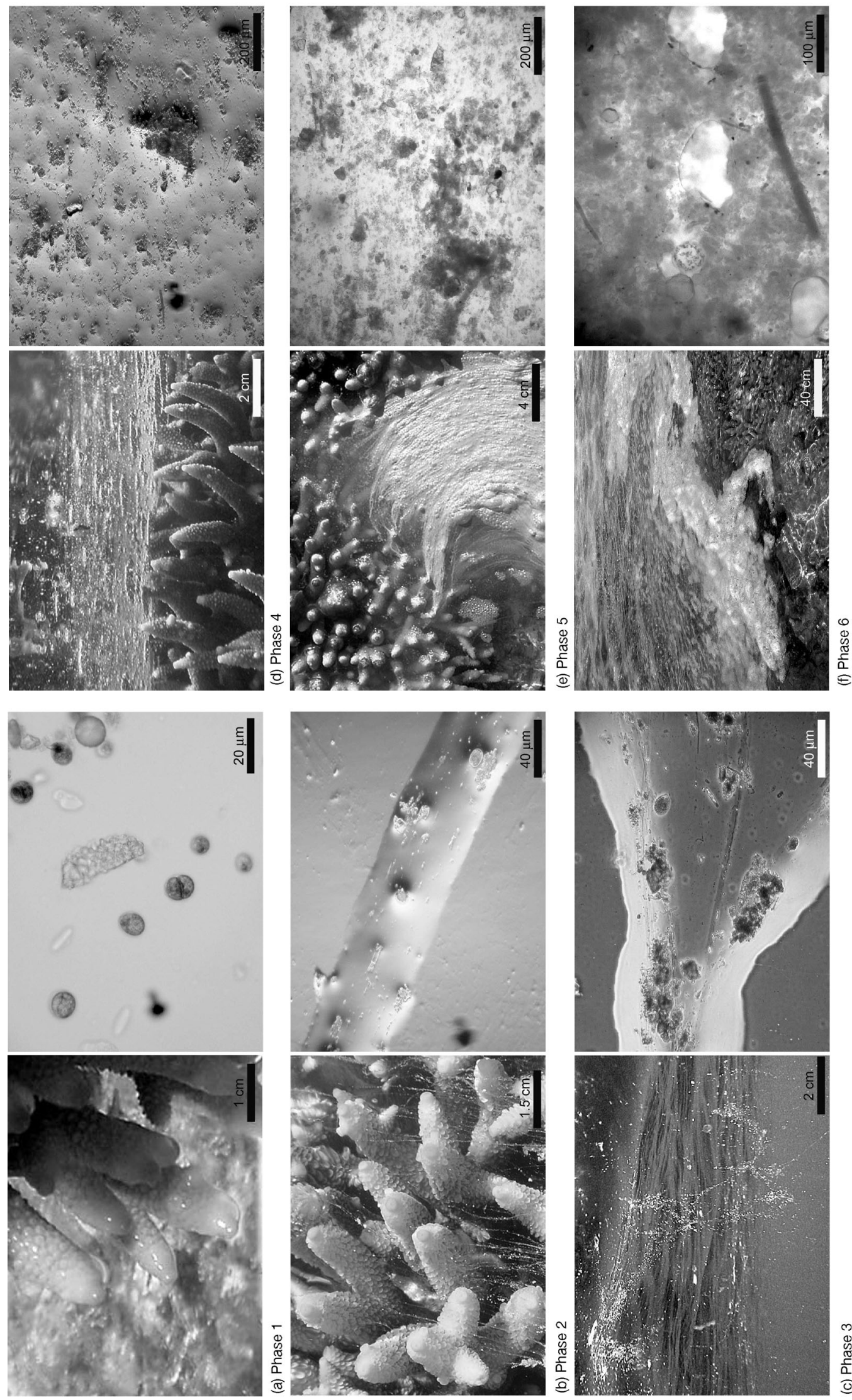

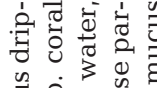

究定出

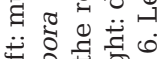

过

안

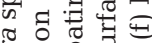

क्ष

:

Ti कि.

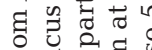

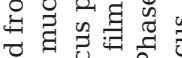

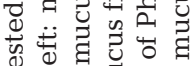

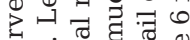

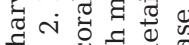

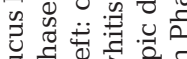

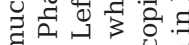

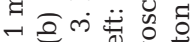

w w

๙

o

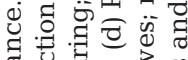

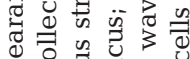

设

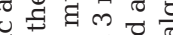

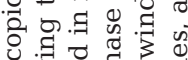

U.

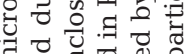

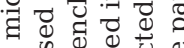

is 0 告

ส․

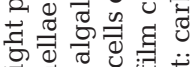

독 0

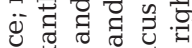

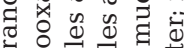

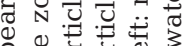

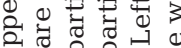

的 2 平

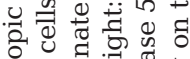

㻤

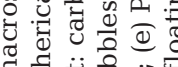

秃

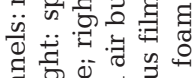

శี

ث.

그의

우워

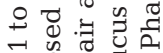

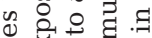

ชै $x$ ठ

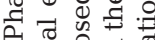

जै 훙

ป 0 o

$\sum$ य क त

o. 의 옹

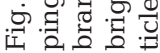


Particles trapped in mucus aggregates

The results of microscopic analyses (Fig. 7) revealed that the content of organic detritus particles and small unidentifiable particles in mucus aggregates increased rapidly over time, and comprised more than $50 \%$ of the aggregate volume within $1 \mathrm{~h}$ after the reef flat was exposed to air. Likewise, the number of trapped carbonate particles increased over time, as did the maximum size of the carbonate grains present in the mucus aggregates $(5,8,15,170 \mu \mathrm{m}$ for Phases 3, 4, 5 and 6, respectively). The abundance of diatoms increased within the first hour, but then stayed more or less constant. Small invertebrates were found in all mucus phases, and their abundance and diversity increased within older mucus phases. Table 2 demonstrates that the highest diversity of taxonomic groups was present in the final 2 phases of the mucus aggregates (5 and 6).

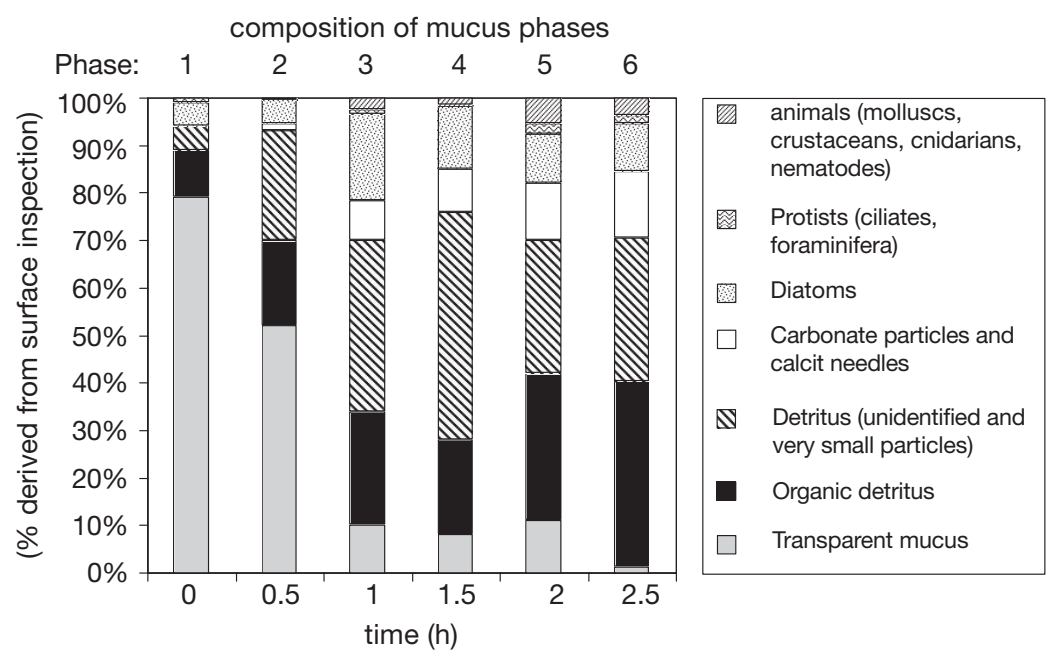

Fig. 7. Composition changes of mucus over time as assessed by microscopic analysis

Table 2. Fauna detected in mucus aggregates

\begin{tabular}{lcccccc|}
\hline & & & & & & \\
& Phase 1 & Phase 2 & Phase 3 & Phase 4 & Phase 5 & Phase 6 \\
\hline Mollusca & - & - & + & + & + & + \\
Polychaeta & - & - & + & + & + & - \\
Oligochaeta & - & - & - & - & + & + \\
Nermertina & - & - & - & - & + & - \\
Plathelmintes & - & - & - & - & + & + \\
Ctenophora & - & + & - & - & + & + \\
Chaetognatha & - & - & - & - & - & + \\
Nematoda & - & - & - & - & + & + \\
Copepoda & + & + & + & + & + & + \\
Copepoda nauplius & - & - & + & + & + & + \\
Ostracoda & - & - & - & - & - & + \\
Mysiidae & - & - & + & - & - & - \\
Cirripedia nauplius & - & - & + & + & + & + \\
Foraminifera & - & - & - & - & + & + \\
Ciliata & + & - & + & + & + & + \\
Rotifera & - & - & - & + & - & - \\
\hline
\end{tabular}

\section{$\mathrm{C}$ and $\mathrm{N}$ content of mucus aggregates}

From Phase 2 to Phase 6, the per unit volume content of carbon and nitrogen in mucus aggregates increased by factors 26 and 79, respectively (Fig. 8). The $\mathrm{C} / \mathrm{N}$ ratio of the mucus aggregates ranged from 10 to 32 with no clear trend, and was higher than that of harvested mucus $(\mathrm{C} / \mathrm{N}=12$, except Phase 6 : $\mathrm{C} / \mathrm{N}=10$ ).

Dry weight and sedimentation rates

The number of carbonate particles and calcite needles in the aggregates increased continuously over time and affected the specific weight and sedimentation rate of the mucus. The trapping efficiency of the mucus was reflected by the difference between the low suspended particle concentration in the seawater and the exponential increase of mucus dry weight over time. This was mostly due to carbonate particles trapped by the mucus (Fig. 9). After approximately $2 \mathrm{~h}$, the dry weight of the mucus had increased by a factor of $35(t=0.5 \mathrm{~h}$, specific dry weight $=169 \pm$ $97 \mathrm{mg} \mathrm{l}^{-1} ; t=2.5 \mathrm{~h}$, specific dry weight $=$ $5993 \pm 221 \mathrm{mg} \mathrm{l}^{-1}$; mean $\pm \mathrm{SD}$ ). The mucus strings, film, layer and floats trapped air bubbles mixed into the water by surface waves, which increased the buoyancy of the mucus aggregates. Bubbles several $\mathrm{mm}$ in diameter were observed in the mucus layer and mucus floats, while in mucus strings and mucus films bubble diameter usually did not exceed $1 \mathrm{~mm}$. Mucus floats with enclosed bubbles floated at the water surface. Floating mucus collected in bottles would release the bubbles and sink after approximately $1 \mathrm{~h}$. In the field, waves and currents accelerated the release of bubbles from the mucus floats, and sinking mucus aggregates could be observed in the reef lagoon of Heron Island shortly after the development of mucus floats (Fig. 10). The sedimentation rate of mucus aggregates without large gas bubble enclosures increased with the age of mucus, and ranged from 0.25 to $1.53 \mathrm{~cm} \mathrm{~s}^{-1}$ in Phase 2 mucus to 4.12 to $7.78 \mathrm{~cm} \mathrm{~s}^{-1}$ in Phase 6 (Fig. 11). On average, the sedimentation rate between Phase 2 and Phase 6 aggregates increased by a factor of 6 . 


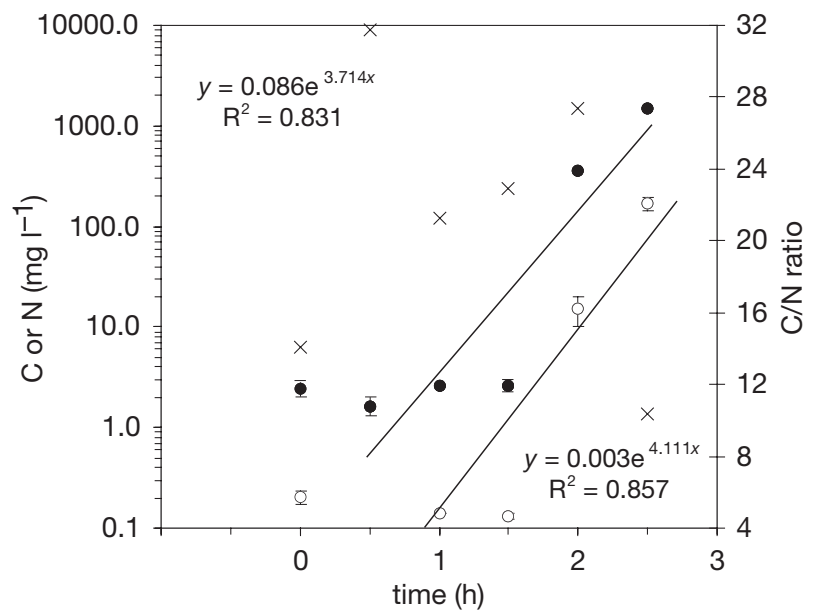

Fig. 8. Changes in $\mathrm{C}(\bullet)$ and $\mathrm{N}(\mathrm{O})$ concentrations, and $\mathrm{C} / \mathrm{N}$ ratios $(X)$ in the mucus aggregates over time. Values from the mucus harvested from corals $(t=0)$ were not used for the regression. Regression lines refer to $\mathrm{C}$ (upper line) and $\mathrm{N}$ (lower line) concentration. Error bars $=\mathrm{SD}, \mathrm{n}=3$

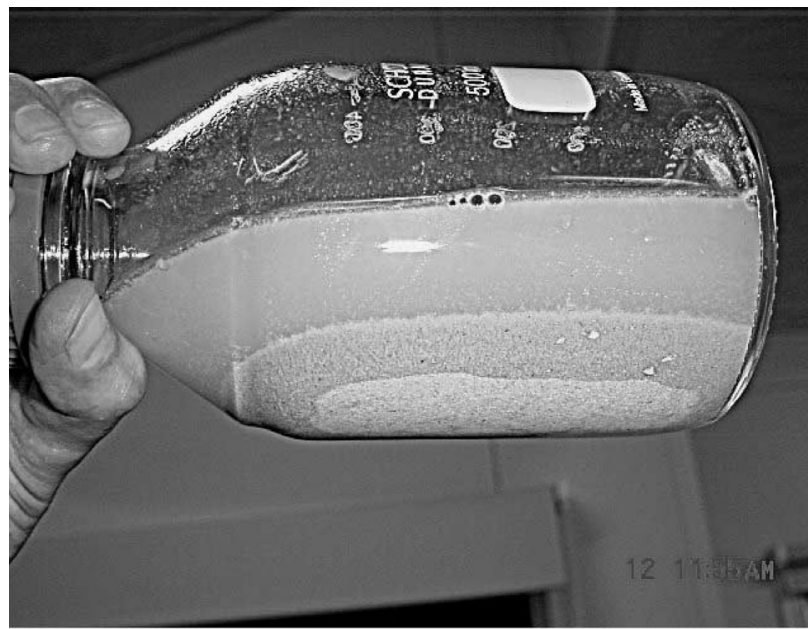

Fig. 9. Sand-size carbonate particles (light deposit in bottle) released after vigorous shaking of Phase 6 mucus aggregates (darker deposit) collected in a bottle

Algal cell abundance, chl $a$ and phaeophytin content

A close inspection of the organic material trapped by mucus revealed that it was comprised of single algal cells and, in Phase 5 and 6, also small algal strings. The abundance of single algal cells in the mucus increased with time, and shortly before sedimentation mucus floats contained up to $1.8 \times 10^{8}$ cells per $\mathrm{ml}\left(8.7 \times 10^{7} \mathrm{SD}, \mathrm{n}=3\right)$ (Fig. 12). Between Phase 2 and Phase 6, cell abundance increased about 3 orders of magnitude. The trapping of algal cells, strings, and detritus was reflected in an exponential increase of chl a (from 1 to $158 \mu \mathrm{g} \mathrm{l}^{-1}$ ) and phaeophytin (from 9 to $122 \mu \mathrm{g} \mathrm{l}^{-1}$ ). The ratio of chl $a$ to phaeophytin increased with the age of mucus, sug-

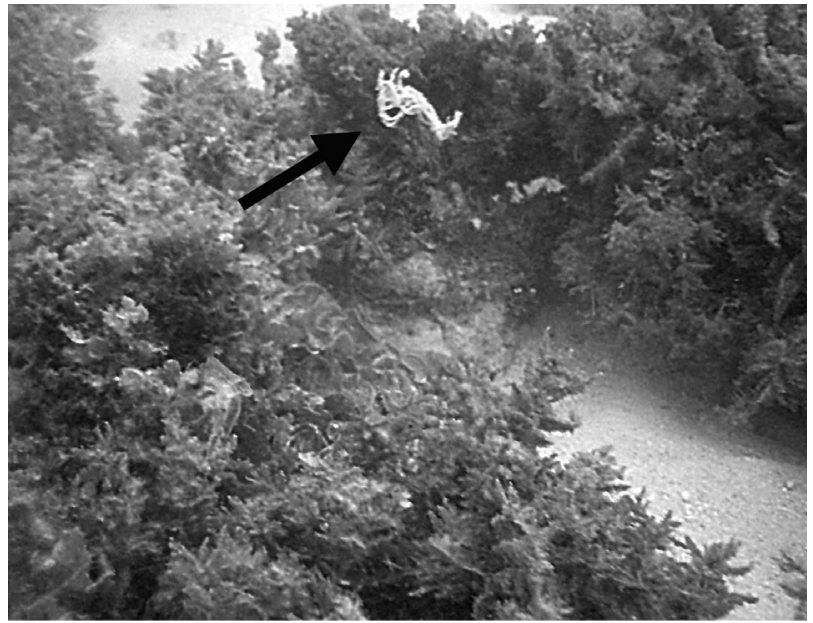

Fig. 10. Mucus aggregate (arrow) sinking to the bottom of the Heron Island reef lagoon

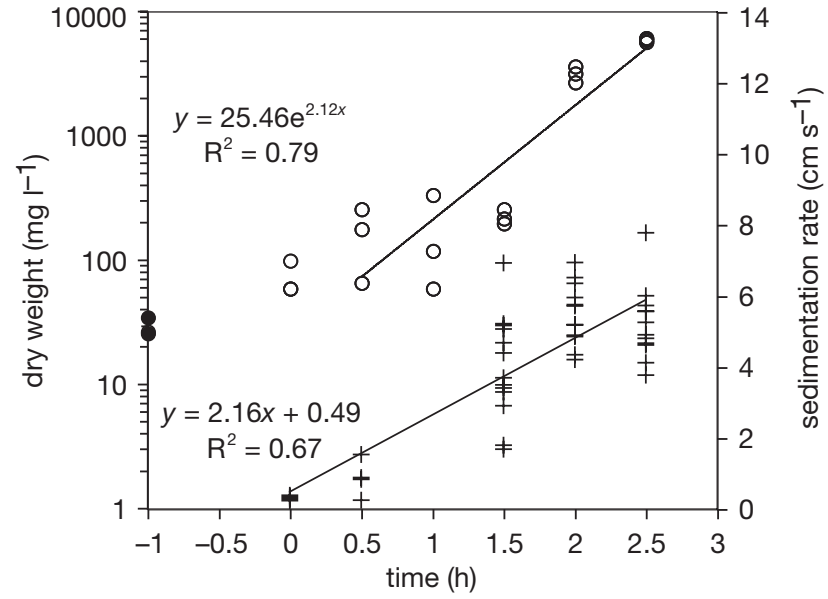

Fig. 11. Dry weights $(0)$ and sedimentation rates $(+)$ of mucus aggregates. Solid circles on the $y$-axis represent suspended particle dry weight in the ambient seawater. Sedimentation rates are given for aggregates of similar size $(1 \pm 0.2 \mathrm{ml})$ without large gas inclusions

gesting that more fresh algal material was trapped as mucus became more viscous over time (Fig. 12). In the second time series, chl a showed a smaller exponential increase over time $\left(y=102.33 \mathrm{e}^{1.38 x}, \mathrm{R}^{2}=0.55\right)$; however, the mucus initially had a higher chl a content $\left(166 \mu^{-1}\right.$ in Phase 2). Highest chl a concentrations were again observed in the 'oldest' mucus, and in this series reached $8133 \mu \mathrm{g} \mathrm{l}^{-1}$ after $2.5 \mathrm{~h}$.

\section{Bacterial abundance}

In a manner similar to that of single algal cells, the number of bacteria in mucus increased over time (Fig. 13). After approximately $1 \mathrm{~h}$, the bacterial density in the mucus $\left(3.5 \times 10^{7}\right.$ cells $\left.\mathrm{ml}^{-1} ; 9.0 . \times 10^{6} \mathrm{SD}, \mathrm{n}=3\right)$ 

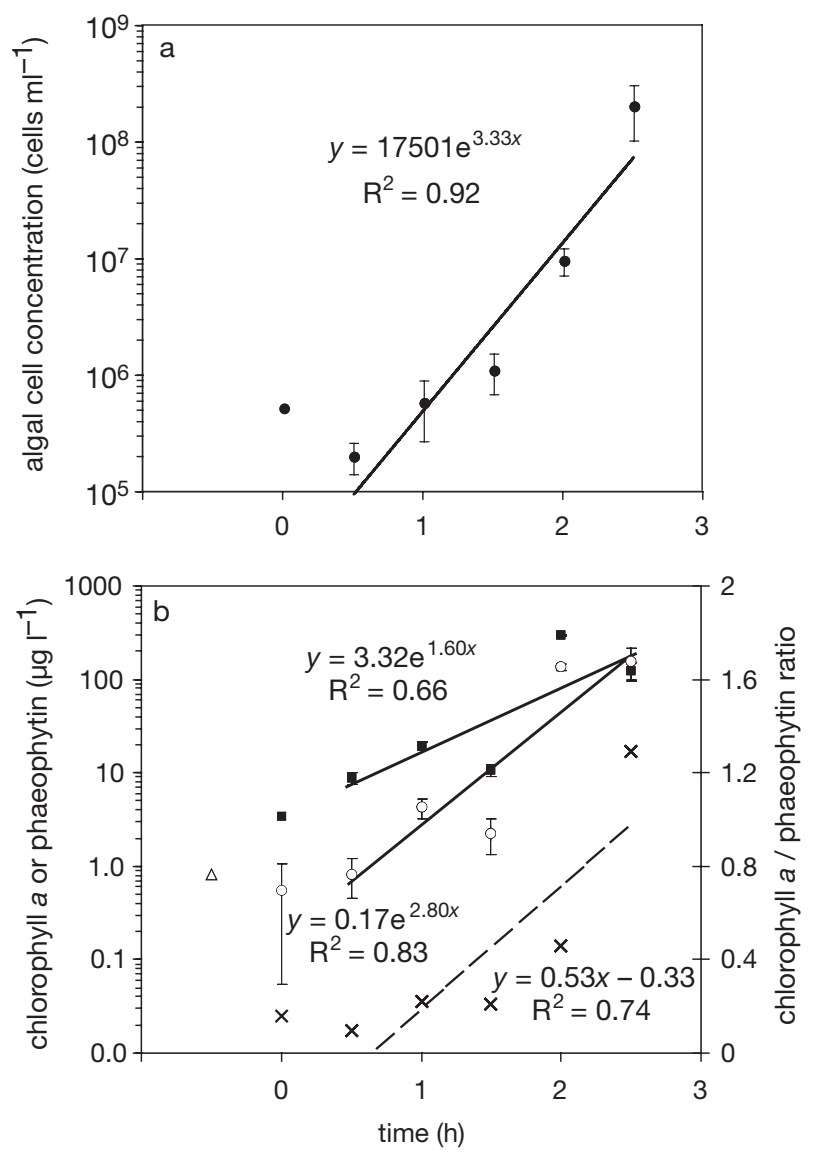

Fig. 12. (a) Single algal cell abundance in the mucus over time; (b) increases of chl a (O), phaeophytin (घ) and chl a/ phaeophytin ratio $(x$, dashed line) with ageing time of the mucus. $(\Delta)$ Chl a concentration in the water on the sampling day. Values from harvested mucus $(t=0)$ were excluded regressions ( $\mathrm{a}$ and $\mathrm{b}$ ). Error bars $=\mathrm{SD}, \mathrm{n}=3$

exceeded that of surrounding seawater $\left(4.3 \times 10^{5}\right.$ cells $\mathrm{ml}^{-1} ; 5.3 \times 10^{4} \mathrm{SD}, \mathrm{n}=3$ ) by a factor of 81 , and at the end of the low tide period had increased to $1.0 \times 10^{10}$ cells $\mathrm{ml}^{-1}\left(3.3 \times 10^{9} \mathrm{SD}, \mathrm{n}=3\right.$; an increase by factor 23866 relative to seawater, and factor 546 relative to Phase 2 aggregates).

\section{DISCUSSION}

Coral mucus is an adhesive organic material that has, among other physiological functions, the purpose of trapping food particles or particles that may prevent light penetration to the zooxanthellae embedded in the tissue of the coral host. Thus, it is a natural glue. It also is a cohesive and elastic viscous fluid, which allows the mucus to cover and flow over the relatively rough surface of scleractinian corals, while producing a continuous surface film. Adhesiveness, cohesiveness, and elasticity persist after the mucus has been washed off the coral by

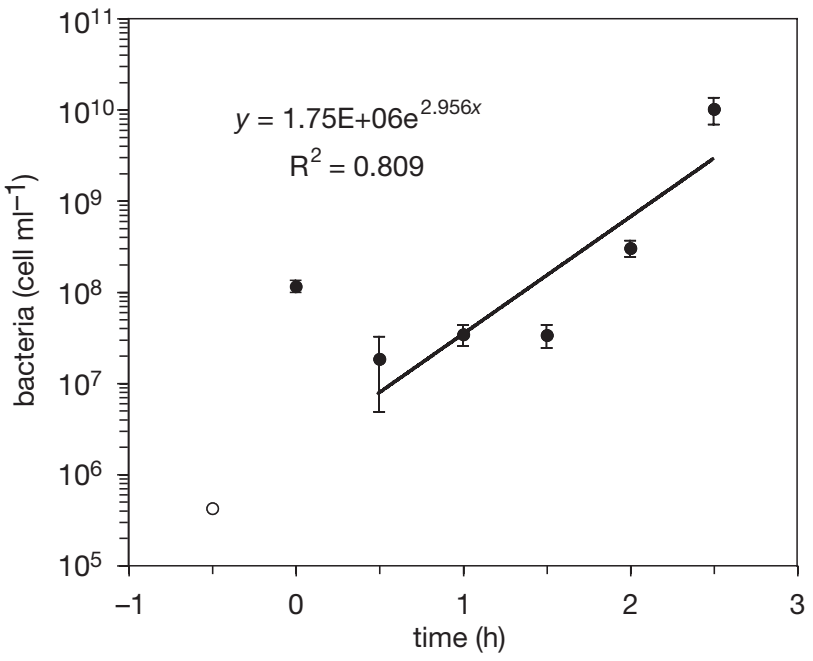

Fig. 13. Bacteria abundances in mucus aggregates $(\bullet)$ and in surrounding seawater (०). Values from harvested mucus $(t=0)$ were excluded from the regression. Error bars $=\mathrm{SD}$,

$$
\mathrm{n}=3
$$

strong currents or waves, or has been released to the water in order to free the coral from excess sediment particles. These properties characterize free-floating mucus as potent traps for particles suspended in the reef water. In this study, we demonstrated that within only 2 to $3 \mathrm{~h}$, free floating mucus accumulated a variety of particles from the ambient water and dramatically changed its appearance, consistency and dry weight, and increased its $\mathrm{C}$ and $\mathrm{N}$ content per unit volume by almost 2 orders of magnitude. Therefore, mucus functions as an efficient particle trap and may have an important function in the cycling of matter in reef ecosystems.

Coral exudates form aggregates through 2 different mechanisms: (1) by the production of gelatinous mucus, which forms transparent exopolymer particles; and (2) by the release of liquid mucus. This 'dissolved mucus' may account for up to $80 \%$ of the coral exudates, and instigated the formation of marine snow aggregates when suspended particles were present in the water, as shown in the roller-table experiments. This marine snow formation may take place close to the corals, where the dissolved mucus concentration is highest. In the roller table experiments, the formation of particle aggregates in seawater with suspensions of bacteria or carbonate particles only occurred in presence of the liquid mucus, except in the experiment with planktonic algae when an aggregate also formed in the control without dissolved mucus. This was not surprising, because the presence of decaying planktonic algae in the water column leads by itself to the formation of marine snow aggregates (Shanks \& Trent 1979).

Gel-like mucus aggregates start as transparent exopolymer particles (TEP) (Schuster \& Herndl 1995, Alldredge et al. 1998) and follow the development reported 
for other marine snow aggregates, formed in the water column through the aggregation of TEP, decaying plankton cells, and detritus (Shanks \& Trent 1979). Marine snow adsorbs suspended particulate matter and is characterized by enhanced bacterial growth, which increases its protein content while sinking in the water column (Kiørboe et al. 2003). Marine snow transfers energy from the phototrophic plankton and the upper water column to the heterotrophic organisms of the deeper water column and sediments (Alldredge \& Silver 1988). Similarly, coral mucus transfers energy from the light-harvesting corals and the passing ocean waters to the reef water and sediment. The key processes of this energy transfer may be divided into 6 consecutive steps:

(1) Production of material with adhesive surface characteristics.

(2) Binding of suspended particles by the adhesive material.

(3) Collision between the resulting adhesive particles and energy-rich suspended particles, leading to aggregate formation and increased particle size and sinking rate.

(4) Colonization of the aggregates by bacteria, with ensuing growth of a microbial community.

(5) Conversion of dissolved nutrients from the water column and organic matter contained in the aggregate to bacterial proteinacious biomass, and subsequent attraction of bacterivores.

(6) Sedimentation of the aggregates, energy transfer to the heterotrophic food chain and benthic system.

Several authors have suggested that coral mucus and mucus-particle aggregates may be a source for nutrients and energy for the microbial food chain and heterotrophic organisms in the reef (Johannes 1967, Coles \& Strathma 1973, Benson \& Muscatine 1974, Ducklow \& Mitchell 1979b), while others argued that mucus particles instead represent a nutrient-poor material with little value for reef organisms (Krupp 1984, Meikle et al. 1988, Coffroth 1990). Krupp (1984) suggested that it was the particles attached to mucus, rather than mucus itself, that converted coral mucus into a valuable food source. In the following, we discuss our results in the context of findings reported for coral mucus and marine snow, and explain how coral mucus aggregates may enhance the recycling of organic matter and nutrients in the oligotrophic reef environment.

\section{Trapping efficiency}

The ecologically important characteristics of coral mucus are its adhesive and cohesive qualities that make it an efficient particle trap. High trapping efficiency is typical for TEP, which form the mucus matrix of most marine snow as well as that of coral mucus aggregates. Alldredge \& McGillivary (1991) reported that the attachment probabilities of natural marine aggregates in the size range from 0.2 to $7.6 \mathrm{~mm}$ are the highest found for natural particles, with 60 to $88 \%$ of collisions with suspended matter resulting in attachment. The attachment probabilities increase with increasing aggregate volume, surface area of contact, and collision velocity. We observed mucus sheaths of up to $10 \mathrm{~cm}$ diameter in the wave breaking zone at the reef crest (Fig. 6c), providing optimal settings for efficient particle trapping. The high cohesiveness of mucus particles is critical to the persistence of mucus flocs in this high energy environment. Alldredge et al. (1990) investigated marine snow settling in a gradient of turbulent kinetic energy, and found that the aggregates did not break apart even at energy dissipation rates $\gg 1 \mathrm{~cm}^{2} \mathrm{~s}^{-3}$. Bacteria that colonize marine snow and produce copious amounts of fibrillar material may maintain and enhance this cohesiveness (Heissenberger et al. 1996). These results support our observation that the coral mucus aggregates of Phases 1 to 3 can resist high turbulence in the reef environment.

\section{Mucus content characteristics}

The strings and sheaths of the net-like mucus flocs resulted in a large complex specific surface area for particle attachment. Accumulation of organic particles from the water column led to rapid increases in the $\mathrm{C}$ and $\mathrm{N}$ content of mucus aggregates; at Heron Island, we found 25 and 79 -fold increases, respectively, within 2 to $3 \mathrm{~h}$. In an investigation of marine snow off coastal California, Alldredge (1998) found that POC, PON, and dry mass content are exponential functions of aggregate volume, and were similar for all aggregates regardless of aggregate type, origin, composition, or season of collection. Diatom aggregates contained the most $\mathrm{C}$ and $\mathrm{N}$, and dry mass was comprised of up to $39 \%$ POC and $6 \%$ PON. In fresh coral mucus, POC content amounted to $2.2 \%$ (3.6\% SD) and PON $0.2 \%(0.1 \% \mathrm{SD})$ of dry mass; in Phase 6 mucus aggregates, these values had increased to $25.9 \%$ POC ( $2.5 \% \mathrm{SD})$ and $2.9 \% \mathrm{PON}(0.5 \% \mathrm{SD})$, thus reaching magnitudes similar to those reported for the rich diatom aggregates investigated by Alldredge (1998). With these values, coral mucus aggregates of the final Phase 6 have a relatively high nitrogen content, while most other reef detritus is nitrogen poor (Coles \& Strathman 1973, Hickel 1974).

In contrast to marine snow, where $\mathrm{C} / \mathrm{N}$ ratios (5 to 11) increase with aggregate size (Alldredge 1998), the $\mathrm{C} / \mathrm{N}$ ratios in coral mucus aggregates (10 to 32 ) did not show a clear trend. The $\mathrm{C} / \mathrm{N}$ ratio of the mucus harvested directly from corals $(\mathrm{C} / \mathrm{N}=14$; can reach 8 [Wild et al. 2005]) was similar to $\mathrm{C} / \mathrm{N}$ ratios found in fresh 
TEP particles produced by diatoms (Mari 1999, Mari et al. 2001). In the initial phases of the aggregate formation, the relatively liquid mucus trapped mostly very small detritus and carbonate particles, which increased the $\mathrm{C} / \mathrm{N}$ ratio to 21-32 (Phases 2 to 5). With increasing viscosity of mucus, larger particles were also caught. This was most pronounced in the final mucus floats (Phase 6), which contained filamentous algae, foraminifera, small crustaceans, and sand grains.

Chl a content and the number of algal cells increased rapidly with age of mucus aggregates, and reached maximum values after $2.5 \mathrm{~h}$ in Phase 6 (Fig. 12). Unexpectedly, the chl a/phaeophytin ratio increased as well, suggesting an increase of the trapped amount of 'fresh' algal material relative to the total amount of phytodetritus accumulated over time. The microscopic analyses revealed abundant living diatom chains and filamentous algae in Phases 4, 5 and 6 aggregates, which supports this hypothesis. Attached pelagic and benthic organisms and bacterial colonization resulted in a $\mathrm{C} / \mathrm{N}$ ratio of 10.5 (0.7 SD) in Phase 6, which was the lowest $\mathrm{C} / \mathrm{N}$ ratio of all mucus phases recorded. A further mechanism that lowered the $\mathrm{C} / \mathrm{N}$ ratio in the final Phase 6 mucus was the attraction of organisms to mucus floats. Coral mucus represents a food source for reef zooplankton (Richman et al. 1975, Daumas et al. 1982, Gottfried 1983), and some of these organisms are trapped by the complex surface of mucus aggregates. Invertebrates were recorded in all mucus aggregates, with copepods being the first taxonomic group found in Phases 1 and 2 (Table 2). In the last 2 phases $(5,6)$ of the mucus aggregates, harpacticoid copepods, ostracods, nematodes, and foraminiferans were found in the mucus aggregates, revealing that benthic animals become trapped when aggregates drift over lagoon sediments.

Because the chances for zooplankton/aggregate encounter are relatively low, Kiørboe (2000) suggested that some zooplankton organisms actively search for aggregates. Shanks \& Walters (1997) observed that copepod nauplii swam into aggregates and were 62 times more concentrated in marine snow compared to surrounding water. Observations compiled from existing literature suggest that zooplankton abundances in marine snow scale with equivalent aggregate radius raised to a power of 2.27 (Kiørboe 2000). Thus, large mucus floats may also have the highest attractiveness to zooplankton. The availability of zooplankton enhances growth and photosynthetic activity of some scleractinian corals (Houlbreque et al. 2003). Corals can therefore directly profit from invertebrate attraction to mucus aggregates.

Increased abundances of ciliates and crustacean and polychaete larvae in marine snow (Artolozaga et al. 1997, Shanks \& delCarmen 1997), as well as in the mucus aggregates, suggests that these aggregates are also an attractive food source for bacterivores. Mari \& Kiørboe (1996) reported that the number of bacteria in TEP scale with TEP size raised to the power of $\sim 1.5$, and argued that this was consistent with the fractal geometry of TEP. Our counts showed an exponential increase of bacterial abundance with increasing age of the mucus aggregates, with a bacterial density in final Phase 6 aggregates that exceeded that of ambient water by 4 orders of magnitude (Fig. 13). There is an increasing amount of evidence that bacteria in seawater can sense chemical gradients and are attracted to sources of nutrient molecules (Mitchell et al. 1996, Blackburn et al. 1998, Azam \& Long 2001, Grossart et al. 2001). Kiørboe et al. (2002) observed that motile bacteria rapidly colonize aggregates, whereas nonmotile bacteria do not, and that tumbling strains colonized aggregates enriched with organic substrates faster than un-enriched aggregates (Kiørboe \& Jackson 2001). These findings indicate that similar to invertebrates, bacteria may also actively move towards mucus aggregates and thus accelerate bacterial colonization and degradation. However, most of the organic matter and nutrients trapped by the mucus cannot be decomposed or released from aggregates within the relatively short floating period, but settle within the reef lagoon along with the mucus.

\section{The coral filter in the reef and the contribution of mucus}

The path of particulate mucus aggregates and dissolved mucus is largely dictated by tidal water movements; combined, this sequence of processes is an effective retention mechanism that feeds oceanic and resuspended particles to cycles of matter in the reef ecosystem (Fig. 14). This mechanism may be partly responsible for the high retention rates of suspended material reported for reef systems similar to that of Heron Island. For Davies Reef on the Great Barrier Reef, Australia, the retention rates of phytoplankton and planktonic microbial communities by the reef rim were estimated to reach values equal to estimates of net community production $\left(0.1 \mathrm{~g} \mathrm{C} \mathrm{m}^{-2} \mathrm{~d}^{-1}\right.$ ) (Ayukai 1995). Furthermore, trapping of planktonic nitrogenfixing cyanobacteria may be a significant source for nitrogen supply to the reef. Ayukai (1995) observed in Davies Reef that the concentrations of cyanobacteria, which accounted for approximately 15 to $50 \%$ of the carbon biomass of phytoplankton in open water, decreased from the reef face towards the leeward reef flat. This distribution is very similar to the POC distribution observed at Heron Island (Wild et al. 2004a), and may partly be due to the trapping of cyanobacteria by coral mucus aggregates. The concentration gradi- 


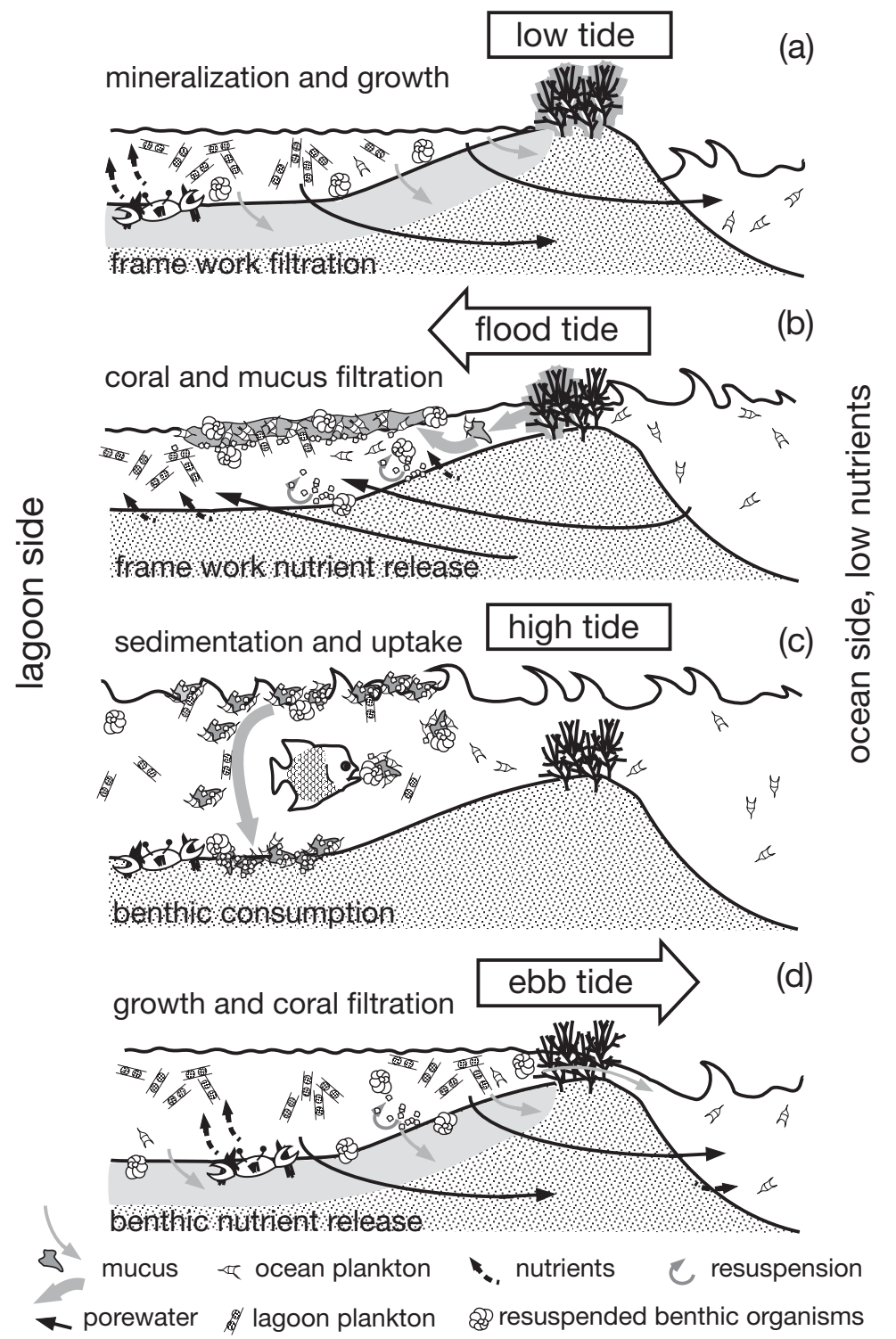

Fig. 14. Coral filter during the spring tide period. (a) At low tide, exposed corals produce large amounts of mucus. (b) Currents of the incoming flood are forced through a sticky filter. New, oceanic particles and bubbles are trapped by mucus on corals and by floating mucus flocs. The rising flood detaches mucus, aggregates form mucus floats and dissolving mucus produces marine snow. Trapped suspended material and microbial growth increase aggregate organic content, while sediment particles enhance specific weight. (c) With increasing water depth, larger waves and stronger currents penetrate into the lagoon destroying and dispersing mucus floats. This leads to release of gas bubbles initiating rapid sedimentation, and in less than $1 \mathrm{~min}$, aggregates reach the bottom next to the corals. Deposited aggregates are rapidly degraded by benthic organisms, releasing nutrients that enhance benthos and plankton growth in the lagoon. (d) During ebb tide, lagoon water is forced through the corals of the circular reef rim. Again, plankton and suspended matter is filtered from the water, but mucus release is smaller because corals were not exposed. Because the water level in the enclosed lagoon drops more slowly compared to outside the reef, the ensuing hydrostatic pressure difference (at Heron Island, $\sim 0.5 \mathrm{~m}$ during spring tides) forces water out of the reef through the lagoon sediment and coral framework (Tribble et al. 1992). Particles and dissolved mucus thus are filtered into the lagoon sediment, where they decompose and release nutrients (Huettel \& Rusch 2000, Wild et al. 2004b). Reversal of the pressure gradient during the pursuing flood forces water in the opposite direction through the reef framework, thereby releasing nutrient-rich pore water to the lagoon enhancing lagoon photosynthetic growth. During tidal cycles without exposure of corals, less mucus is produced, but the general functioning of this cycle is similar

ents of cyanobacteria and POC reflect the transport of these particles into the lagoon and a concurrent scavenging process that may partially be caused by coral mucus trapping.

The amount of organic carbon carried into the lagoon can be estimated using the mucus release rates reported in the literature, or by using our POC measurements in the water above the reef rim. The reef rim at our measuring site was approximately $100 \mathrm{~m}$ wide (Fig. 1). A $100 \mathrm{~m}$ section of the reef rim $\left(10000 \mathrm{~m}^{2}\right)$ had on average a hard coral coverage of $4000 \mathrm{~m}^{2}$, with a total coral surface area of approximately $15200 \mathrm{~m}^{2}$ (Wild et al. 2004a, Wild et al. 2005). According to Wild et al. (2005), the dominating Acropora spp. corals released 0.31 (submerged) to 3.81 (exposed) mucus $\mathrm{m}^{-2}$ coral surface $\mathrm{h}^{-1}$. For a $100 \mathrm{~m}$ wide section, this would amount to 18240 (no exposure) to 714401 (3 h without,
$1 \mathrm{~h}$ with exposure) within our $4 \mathrm{~h}$ observed flooding period, if we assume similar mucus release rates for other hard corals that contributed $60 \%$ to the total hard coral coverage.

Freshly exuded coral mucus contained on average $24.6 \mathrm{mg} \mathrm{Cl}^{-1}$ (Fig. 8); thus, the above calculated mucus release would correspond to a carbon release of 0.45 to $1.76 \mathrm{~kg} \mathrm{C}$ per $10000 \mathrm{~m}^{2}$ of reef rim area, or 0.31 to $1.21 \mathrm{t}$ $\mathrm{C}$ for the entire reef rim $\left(6.9 \mathrm{~km}^{2}\right)$ during the $4 \mathrm{~h}$ flooding period. We can calculate a second estimate for the mucus-enhanced $\mathrm{C}$ flux into the lagoon using the POC values that we recorded over the reef rim during flooding on January 13 and 27, 2002 (Fig. 3). During the POC sampling, we recorded water height and current velocity and, using these data, we could estimate the time period needed to replace the water over the reef rim by incoming flood water. The current velocities of 
the incoming tide ranged between 4 and $45 \mathrm{~cm} \mathrm{~s}^{-1}$, and roughly replaced the water over the reef rim within 4 to 42 min during the $4 \mathrm{~h}$ observed period. During this time, water depth over the reef rim sampling site increased from 40 to $110 \mathrm{~cm}$, causing a water volume increase of 4000 to $11000 \mathrm{~m}^{3}$ over the $10000 \mathrm{~m}^{2}$ of reef rim area. Using the water exchange rate over the $10000 \mathrm{~m}^{2}$ reef rim section, we obtained masses of 9.4 and $31.7 \mathrm{~kg} \mathrm{C}$ that were transported into the reef lagoon during the $4 \mathrm{~h}$ flooding period on January 13 and 27 , respectively. This is considerably more than the 0.45 to $1.76 \mathrm{~kg} \mathrm{C}$ per $10000 \mathrm{~m}^{2}$ and $4 \mathrm{~h}$ carbon release via mucus calculated using mucus release rates reported by Wild et al. (2004a, 2005), and suggests that mucus contributes only a modest amount to total POC in the water column.

The above discrepancy may be due to an underestimation of mucus release rates, or to other factors that increase POC and nutrients in the reef water during low tide (e.g. activities of bottom dwellers, resuspension). However, mucus is a key factor that traps POC from the water column. If we assumed that mucus aggregates released from the coral during the $4 \mathrm{~h}$ flooding period trapped particles for (on average) $2 \mathrm{~h}$, then according to our measurements the carbon content of aggregates increased by a factor of 5.9 during the study period (Fig. 8). When we multiplied the carbon release rates given by Wild et al. (2004a) for mucus by this factor, we arrived at 2.6 to $10.3 \mathrm{~kg} \mathrm{C}$ per $10000 \mathrm{~m}^{2}$ of reef rim area that was transported as mucus aggregates into the lagoon during the $4 \mathrm{~h}$ flooding period. This suggests that mucus aggregates contributed approximately one-third of the POC that was transported into the reef lagoon and, due to the high sinking rates of aggregates, this material was then made available to the lagoon system. Based on our POC measurements in the water above the reef rim, and supported by calculations of Wild et al. (2004a) based on mucus release from corals, the trapped material supplied up to 2 to $7 \mathrm{t}$ POC to the entire reef ( $6.9 \mathrm{~km}^{2}$ reef rim) during the $4 \mathrm{~h}$ flooding period. These estimates underline the importance of the trapping of suspended particulate matter by coral mucus, which enhanced the carbon content of mucus aggregates transported into the lagoon by a factor of $\sim 6$.

\section{Summary}

The production of coral mucus and ensuing aggregate formation reduces the loss of resuspended matter and enhances the import of oceanic particles to the reef system. The rapid uptake of particulate matter, and increase in $\mathrm{C}$ and $\mathrm{N}$, and chlorophyll content within only $2 \mathrm{~h}$, reveals the trapping efficiency of the mucus. The tidal pressure gradient between the water levels of the lagoon and the ocean surrounding the reef, and the high sinking rates of the mucus aggregates, ensures that material caught by the mucus aggregates remains in the reef ecosystem, close to the corals. The rapid colonization of mucus aggregates by bacteria and bacterivores, and consumption by reef invertebrates and fish, promotes the release of nutrients from the organic particles trapped in the mucus aggregates and therefore supports benthic and pelagic primary production in the reef ecosystem. This production and associated secondary production, as well as the release of DOC during aggregate decomposition, provides food for the corals and thus partly compensates for the loss of energy and nutrients associated with the release of mucus. We conclude that coral mucus aggregates enhance the recycling of matter in the reef ecosystem and provide a mechanism that can effectively strip particles from ocean water passing over the reef, thereby supporting the high production observed for coral reefs in the oligotrophic ocean.

Acknowledgements. We thank B. B. Jørgensen for supporting this work, and O. Hoegh-Guldberg for making the research at Heron Island possible. R. Forbes of HIRS was a great help when setting up the laboratory and experiments. S. Kremb, H. Woyt, S. Menger, M. Alisch and L. Hönemann assisted with sampling and the analyses. The comments of 3 anonymous reviewers improved the manuscript. Sample collections and in situ experiments were conducted under permits QC00/102, G01/479 and G01/601 granted by the Great Barrier Reef Marine Park Authority. The research was funded by the Max Planck Society and the Centre for Marine Studies, University of Queensland, Australia.

\section{LITERATURE CITED}

Alldredge A (1998) The carbon, nitrogen and mass content of marine snow as a function of aggregate size. Deep-Sea Res Part I 45:529-541

Alldredge AL, McGillivary P (1991) The attachment probabilities of marine snow and their implications for particle coagulation in the ocean. Deep-Sea Res Part A 38:431-443

Alldredge AL, Silver MW (1988) Characteristics, dynamics and significance of marine snow. Prog Oceanogr 20:41-82

Alldredge AL, Granata TC, Gotschalk CC, Dickey TD (1990) The physical strength of marine snow and its implications for particle disaggregation in the ocean. Limnol Oceanogr 35:1415-1428

Alldredge AL, Passow U, Haddock SHD (1998) The characteristics and transparent exopolymer particle (TEP) content of marine snow formed from thecate dinoflagellates. J Plankton Res 20:393-406

Artolozaga I, Santamaria E, Lopez A, Ayo B, Iriberri J (1997) Succession of bacterivorous protists on laboratory-made marine snow. J Plankton Res 19:1429-1440

Ayukai T (1995) Retention of phytoplankton and planktonic microbes on coral-reefs within the Great-Barrier-Reef, Australia. Coral Reefs 14:141-147 
Azam F, Long RA (2001) Oceanography - sea snow microcosms. Nature 414:495-498

Barnes R, Hughes R (1999) An introduction to marine ecology, 3rd edn. Blackwell Science, Oxford

Benson A, Muscatine L (1974) Wax in coral mucus - energy transfer from corals to reef fishes. Limnol Oceanogr 19: 810-814

Blackburn N, Fenchel T, Mitchell J (1998) Microscale nutrient patches in planktonic habitats shown by chemotactic bacteria. Science 282:2254-2256

Brown BE, Bythell, JC (2005). Perspectives on mucus secretion in reef corals. Mar Ecol Prog Ser 296:291-309

Coffroth MA (1983) Cyclical formation of mucus sheets by 3 coral species. Am Zool 23:960-960

Coffroth MA (1990) Mucous sheet formation on poritid corals - an evaluation of coral mucus as a nutrient source on reefs. Mar Biol 105:39-49

Coles SL, Strathma R (1973) Observations on coral mucus flocs and their potential trophic significance. Limnol Oceanogr 18:673-678

Crossland C (1987) In situ release of mucus and DOC-lipid from the corals Acropora variabilis and Stylophora pistillata in different light regimes. Coral Reefs 6:35-42

Crossland C, Barnes D, Borowitzka M (1980) Diurnal lipid and mucus production in the staghorn coral Acropora acuminata. Mar Biol 60:81-90

Daumas R, Galois R, Thomassin B (1982) Biochemical composition of soft and hard coral mucus on a new Caledonian lagoonal reef. Proc 4th Int Coral Reef Symp, Manila, 2:59-68

Davies PS (1984) The role of zooxanthellae in the nutritional energy requirements of Pocillopora eydouxi. Coral Reefs 2:181-186

Ducklow H, Mitchell R (1979a) Bacterial populations and adaptations in the mucus layers on living corals. Limnol Oceanogr 24:715-725

Ducklow HW, Mitchell R (1979b) Composition of mucus released by coral reef coelenterates. Limnol Oceanogr 24: 706-714

Gottfried MRM (1983) Ingestion and incorporation of coralmucus detritus by reef zooplankton. Mar Biol 72:211-218

Grasshoff K, Kremling K, Ehrhardt M (1999) Methods of seawater analysis, 3rd edn. Wiley-VCH, Weinheim

Grossart HP, Riemann L, Azam F (2001) Bacterial motility in the sea and its ecological implications. Aquat Microb Ecol 25:247-258

Hatcher BG (1990) Coral reef primary productivity: a hierarchy of pattern and process. Trends Ecol Evol 5:149-155

Hatcher BG (1997) Coral reef ecosystems: how much greater is the whole than the sum of the parts? In: Lessios HA, Macintyre, IG (eds) Proc 8th Int Coral Reef Symp, Panama City, 1:43-56

Hayes RL, Goreau NI (1998) The significance of emerging diseases in the tropical coral reef ecosystem. Rev Biol Trop 46:173-185

Heissenberger A, Leppard GG, Herndl GJ (1996) Ultrastructure of marine snow. 2. Microbiological considerations. Mar Ecol Prog Ser 135:299-308

Hickel W (1974) Seston composition of the bottom waters of Great Lameshur Bay, St. John, US Virgin Islands. Mar Biol 24:125-130

Hobbie JE, Daley RJ, Jasper S (1977) Use of nuclepore filters for counting bacteria by fluorescence microscopy. Appl Environ Microbiol 33:1225-1228

Hoppe H, Schramm W, Bacolod P (1988) Spatial and temporal distribution of pelagic microorganisms and their proteolytic activity over a partly destroyed coral reef. Mar Ecol Prog Ser 44:95-102
Houlbreque F, Tambutte E, Ferrier-Pages C (2003) Effect of zooplankton availability on the rates of photosynthesis, and tissue and skeletal growth in the scleractinian coral Stylophora pistillata. J Exp Mar Biol Ecol 296:145-166

Hubbard JAEB, Pocock YP (1972) Sediment-rejection by recent scleractinian corals: a key to palaeo-environmental reconstruction. Geol Rundsch 61:598-626

Huettel M, Rusch A (2000) Transport and degradation of phytoplankton in permeable sediment. Limnol Oceanogr 45:534-549

Johannes R (1967) Ecology of organic aggregates in the vicinity of a coral reef. Limnol Oceanogr 12:189-195

Kato M (1987) Mucus-sheet formation and discoloration in the reef-building coral, Porites cylindrica: effects of altered salinity and temperature. Galaxea 6:1-16

Kiørboe T (2000) Colonization of marine snow aggregates by invertebrate zooplankton: abundance, scaling, and possible role. Limnol Oceanogr 45:479-484

Kiørboe T, Jackson GA (2001) Marine snow, organic solute plumes, and optimal chemosensory behavior of bacteria. Limnol Oceanogr 46:1309-1318

Kiørboe T, Grossart HP, Ploug H, Tang K (2002) Mechanisms and rates of bacterial colonization of sinking aggregates. Appl Environ Microbiol 68:3996-4006

Kiørboe T, Tang K, Grossart HP, Ploug H (2003) Dynamics of microbial communities on marine snow aggregates: colonization, growth, detachment, and grazing mortality of attached bacteria. Appl Environ Microbiol 69:3036-3047

Krupp D (1984) Mucus production by corals exposed during an extreme low tide. Pac Sci 38:1-11

Krupp DA (1985) An immunochemical study of the mucus from the solitary coral Fungia scutaria (Scleractinia, Fungiidae). Bull Mar Sci 36:163-176

Lewis JB (1977) Processes of organic production on coral reefs. Biol Rev Camb Phil Soc 52:305-347

Lewis JB (1978) Feeding mechanisms in black corals (Antipatharia). J Zool 186:393-396

Lewis JB, Pice WS (1976) Patterns of ciliary currents in Atlantic reef corals and their functional significance. J Zool 178:77-89

Loya Y, Rinkevich B (1980) Effects of oil pollution on coral reef communities. Mar Ecol Prog Ser 3:167-180

Mari X (1999) Carbon content and C:N ratio of transparent exopolymeric particles (TEP) produced by bubbling exudates of diatoms. Mar Ecol Prog Ser 183:59-71

Mari X, Kiørboe T (1996) Abundance, size distribution and bacterial colonization of transparent exopolymeric particles (TEP) during spring in the Kattegat. J Plankton Res 18:969-986

Mari X, Beauvais S, Lemee R, Pedrotti ML (2001) Non-Redfield C:N ratio of transparent exopolymeric particles in the northwestern Mediterranean Sea. Limnol Oceanogr 46: 1831-1836

Marshall M (1968) Observations on organic aggregates in the vicinity of coral reefs. Mar Biol 2:50-55

Meikle P, Richards G, Yellowlees D (1988) Structural investigations on the mucus from six species of coral. Mar Biol 99: 187-193

Mitchell JG, Pearson L, Dillon S (1996) Clustering of marine bacteria in seawater enrichments. Appl Environ Microbiol 62:3716-3721

Muscatine L, D’Elia C (1978) The uptake, retention, and release of ammonium by reef corals. Limnol Oceanogr 23: 725-734

Richman S, Loya Y, Slobodkin L (1975) Rate of mucus production by corals and its assimilation by the coral reef copepod Acartia negligens. Limnol Oceanogr 20:918-923 
Romaine S, Tambutte E, Allemand D, Gattuso JP (1997) Photosynthesis, respiration and calcification of a zooxanthellate scleractinian coral under submerged and exposed conditions. Mar Biol 129:175-182

Rublee P, Lasker H, Gottfried M, Roman M (1980) Production and bacterial colonization of mucus from the soft coral Briarium asbestinum. Bull Mar Sci 30:888-893

Schuhmacher H (1977) Ability of fungiid corals to overcome sedimentation. Proc 3rd Int Coral Reef Symp, Miami, p 503-509

Schuster S, Herndl GJ (1995) Formation and significance of transparent exopolymeric particles in the northern Adriatic Sea. Mar Ecol Prog Ser 124:227-236

Shanks AL, delCarmen KA (1997) Larval polychaetes are strongly associated with marine snow. Mar Ecol Prog Ser 154:211-221

Shanks AL, Edmondson EW (1989) Laboratory-made artificial marine snow - a biological model of the real thing. Mar Biol 101:463-470

Shanks AL, Trent JD (1979) Marine snow - microscale nutrient patches. Limnol Oceanogr 24:850-854

Shanks AL, Walters K (1997) Holoplankton, meroplankton, and meiofauna associated with marine snow. Mar Ecol Prog Ser 156:75-86

Sorokin YI (1991) Parameters of productivity and metabolism of coral-reef ecosystems off central Vietnam. Estuar Coast Shelf Sci 33:259-280

Strickland JDH, Parsons TR (1972) A practical handbook of

Editorial responsibility: Howard I. Browman

(Associate Editor-in-Chief), Storebø, Norway seawater analysis. 2nd edn. Bull Fish Res Borad Can 167

Teai T, Drollet JH, Bianchini JP, Cambon A, Martin PMV (1998) Occurrence of ultraviolet radiation-absorbing mycosporine-like amino acids in coral mucus and whole corals of French Polynesia. Mar Freshw Res 49:127-132

Telesnicki G, Goldberg W (1995) Effects of turbidity on the photosynthesis and respiration of 2 South Florida reef coral species. Bull Mar Sci 57:527-539

Thomas FIM, Atkinson MJ (1997) Ammonium uptake by coral reefs: effects of water velocity and surface roughness on mass transfer. Limnol Oceanogr 42:81-88

Tribble GW, Sansone FJ, Buddemeier RW, Li Y-H (1992) Hydraulic exchange between a coral reef and surface sea water. Geol Soc Am Bull 104:1280-1291

Vacelet E, Thomassin B (1991) Microbial utilization of coral mucus in long term in situ incubation over a coral reef. Hydrobiologia 211:19-32

Wild C, Huettel M, Klueter A, Kremb SG, Rasheed MYM, Jorgensen BB (2004a) Coral mucus functions as an energy carrier and particle trap in the reef ecosystem. Nature 428: $66-70$

Wild C, Rasheed M, Werner U, Franke U, Johnstone R, Huettel M (2004b) Degradation and mineralization of coral mucus in reef environments. Mar Ecol Prog Ser 267: 159-171

Wild C, Woyt H, Huettel M (2005) Influence of coral mucus on nutrient fluxes in carbonate sands. Mar Ecol Prog Ser 287: $87-98$

Submitted: April 6, 2005; Accepted: August 23, 2005

Proofs received from author(s): January 12, 2006 